\title{
One Hundred Years of Inertia An Exposé of the Concept of the Psychosocial Work Environment in Swedish Policy and Research
}

I Lena Abrahamsson

Professor in Human Work Sciences, Luleå University of Technology, Sweden

\section{Jan Johansson'}

Professor in Human Work Sciences, Luleå University of Technology, Sweden

\begin{abstract}
The purpose of this article is to describe a broader concept of the psychosocial work environment, a concept that not only is limited to the individual and her immediate environment but also takes into account a broader context that includes production technology as well as work organization and learning. Based on examples from Sweden, we discuss concepts and approaches to psychosocial work environment and how these have changed over time (e.g., how knowledge about the psychosocial work environment is used to understand and discuss health, management, and development - for individuals, groups, and organizations). The knowledge presented is not new; it has been around a long time. The title of the article - One Hundred Years of Inertia - shows some impatience on the part of its authors given that the pace of change in the work environment has not always been great.
\end{abstract}

\section{KEYWORDS}

Psychosocial work environment / Work organization / Swedish Policy and Research

\section{Introduction}

\begin{abstract}
- he purpose of this article is to broaden the view of the concept of psychosocial work environment. The article is based on our reading of some of the large amount of previous research, and we try to place the concept in a context that includes both management concepts and trade union practices. We start off with a discussion of the concept of psychosocial work environment. Thereafter, we attempt a journey where we discuss how the concept has been interpreted in different times and contexts. Our intention is not to provide comprehensive coverage of theory development, but rather to show the breadth of aspects that are and can be included in the concept of psychosocial work environment. Finally, we reflect on how the concept could be recognized in the future.
\end{abstract}

\section{What is psychosocial work environment?}

Psychosocial work environment is an established, widely used concept in Sweden, particularly when it comes to explaining problems such as stress and illness. There also exists

\footnotetext{
${ }^{1}$ E-mail: Jan.Johansson@ltu.se
} 
a great deal of general and media interest in psychosocial work environment concepts. The term "psychosocial" is said to have first been used in Sweden in 1959 by psychoanalyst Erik Erikson, although the Austrian British social psychologist, Marie Jahoda, had discussed sociopsychological problems for girls employed in factories as early as 1941. The psychosocial work environment assumed a definite place in Swedish discussions about the work environment when a new Work Environment Act was introduced in 1977. The Swedish Work Environment Act (SFS 1977) emphasizes a holistic view and assigns the psychosocial and work organizational aspects of the work environment a prominent role. The concept of the psychosocial work environment is exceedingly relevant today. The Swedish Work Environment Authority has identified the psychosocial dimension as important in today's work environment and has begun a project to design overarching rules to regulate it.

One common way to explain psychosocial work environment is that it refers to people's interaction with their surroundings. This not only includes how people are affected by their work environment but also relates to how people are developed by and, in turn, how they develop their work environment. From this perspective, it is clear that the psychosocial environment includes an individual's interaction with all aspects of their work situation (see, e.g., AFS 1980). In other words, it does not only refer to relations between people. Neither is there a distinct part of the work environment that is "psychosocial." People always interact with their work environment as a whole. It is not possible to differentiate between the "physical work environment" (the body, room, technology, and organizational structure) and the "psychological work environment" (the mind, symbols, discourses, relations, and individuals). This division into physical and psychological can be used, however, as a pedagogical device to describe the psychological and social consequences of the work environment. The concept of the psychosocial work environment is further complicated by the fact that the same work environment can affect different people in different ways.

\section{What is a good psychosocial work environment?}

As shown by the discussion above, it is difficult to answer that question without broadening it to what is a good work environment. The psychosocial parts can be incised on many axes, but it is just the slicing we want to problematize and instead point to a broader context. The existing knowledge about what characterizes a good work environment is both comprehensive and well documented. It has been developed over decades across several different fields of research and has been heavily influenced by interdisciplinary and international exchange. In Sweden, there exist both a generally agreed upon concept of and useful guidelines for, achieving good working conditions, in which the psychosocial work environment plays a central role (see, e.g., Abrahamsson et al. 2003, Johansson and Abrahamsson 2008, Theorell 2003, Thylefors 2008).

If we were to attempt to summarize a good work environment (based on many of the theories presented later on in this article), the summary might look something like this: In a good work environment, not only are physical risks and problems eliminated, and equipment and work sites are adapted to suit people's different physical and psychological make-up and designed to make work easier, but employees also enjoy autonomy and a sense of participation and influence in matters both large and small. These involve being 
able to influence the division of duties and the pace and method of working, in relation to both other people and to the technical system used. In a good working environment, work provides physical, intellectual and cultural stimulation, variety, opportunities for social interactions, context, and opportunities for learning and for personal and professional development. Here, workloads, demands, and challenges (both physical and psychological) are balanced at a reasonable level. The workplace is also characterized by gender equality, fairness, respect, trust, democratic leadership, and open communication and offers good opportunities for enjoyment and social support. There should also be good opportunities to combine work with a rich and sustainable life outside of work. A poor work environment can result in a reduction in individuals' quality of life, commitment, and general stamina. There are also factors that are partially external to the workplace, but which affect it, the individuals who work there, and the psychosocial work environment. These may include everything from an unstable or distorted local labor market and poor educational and rehabilitation systems to insecurity and violence, as well as heavy demands on, and responsibility for, unpaid care work done in the home.

\section{Benefits for both the company and the individual}

In Sweden, there is also a consensus concerning arguments in favor of improvements to the work environment, even if these vary depending on whether the point of departure is the business community, societal development, and/or simply the desire to prevent injuries and ill-health and promote quality of life. The socioeconomic viewpoint is an important motivating force. Absences from work, treatment, retraining, sick leave, and rehabilitation generate major costs not only for society but also for businesses. In Sweden in recent years, an attitude has also developed (partly inspired by our Nordic neighbors) that a good work environment is also a political issue and a strategic instrument for achieving social progress. Ensuring a good work environment makes it possible for more people to work, which contributes to favorable societal development.

In recent decades, work organization, employee relations, and the psychosocial work environment have assumed increasing importance in discussions about the opportunities of businesses to compete, grow, and survive. The path of development has gone from noise reduction to coaching and from viewing the work environment as an area for problems to viewing it as an area for workplace learning and for strategic development from management. We have become used to organizational changes and dealing with popular trends among both organizations and management. In today's management, catchwords like organizational development, leadership, motivation, and learning, as if these were a matter of course. New forms of work organization have also been presented as solutions to health- and work environment-related problems, as well as to recruitment problems. It is also hoped that these will also help resolve high unemployment and the productivity and competition problems of the Swedish industry. The importance of innovation in the business world is being emphasized as a means to increase growth and create more job opportunities. There is also currently a strong realization that innovations cannot be fully exploited if they are not complemented by organizational changes and new work methods. The Swedish government's reports (Ds 2008:16) state that organizational changes and the development of new technology are among the most important factors in the current increase in productivity being observed. 
The above reasoning is typical of the Swedish working life's win-win perspective, with two integrated objectives: firstly, efficient and progressive production and secondly, good health and learning among employees. Occasionally, this concept is expressed using terms like "sustainability" or "resilience." The link at the company level between profitability and the psychosocial work environment is difficult to measure, however, particularly from a short-term perspective. It is difficult to know what the true cause is behind the effect, and things like corporate-wide decisions or recessions can quickly distort these apparent links. However, even if it is difficult to estimate an organization's monetary or productivity value, there are solid indications that an organization with a good psychosocial work environment functions better, is easier to develop, and provides better opportunities for flexibility, cooperation, professional development, and innovation. In any case, it is clear that a good psychosocial work environment leads to improved physical and psychological heath, greater enjoyment, lower staff turnover, fewer cases of sick leave, increased commitment, and better performance (Spector 1986). It is presumably as simple as saying that people who feel good perform well. People who are exposed to long periods of work in a poor work environment react to this sooner or later-physically, mentally, and/or socially. These reactions can have a negative impact on the work environment, the individual, and the level of efficiency.

\section{Three areas/perspectives}

In spite of the prevailing consensus, the psychosocial work environment is a multifaceted concept that has a rocky history. In both day-to-day practice and research, there are different areas or perspectives that intertwine and that enrich one another, although sometimes parallel discussions occur that can confuse and contradict one another. In this article, partly inspired by Aronsson et al. (2012), we choose to divide psychosocial work environment into three large areas, even though doing so is somewhat of a simplification.

We call the first area "health/illness." Here, the focus is on health problems that can be remedied. Stress is a large and central theme. Another central theme is the attitudes, needs, and motivation of the individual. This includes discussions of such things as the body's alarm system, stress factors, coping, locus of control, and sense of context. In recent years, there has been a growing interest in the individual's health, well-being, and empowerment, leading to an initiation of a search for health factors in working life. Many large businesses and organizations conduct annual assessments of these aspects in the form of employee surveys, indexes, and "balanced scorecards." The results of these surveys are reported in the form of "satisfied employee indexes."

We call the second area "management and development." Here, the focus is on opportunities that can be utilized to manage and develop an organization, groups, and individuals. A common theme is work groups and how they function. This includes discussions about cooperation, group processes, and different group types-such as teams, informal groups and subgroups, as well as cultures, norms, roles, discrimination, and conflicts. One central theme is leadership and discussions include leadership qualities, leadership styles, power, manipulation, and reactions. Other themes in this area deal with learning-both individual and collective-as well as organizational changes.

The third area we have called "problematization." This area deals more with questioning, critical analyses, and complementary understandings of different phenomena 
within the psychosocial work environment, such as power systems, alienation, opposition, and inequality. This area includes discussions about myths, prejudices, gender, social constructions, workplace culture, professional identities, and discourses, for example. It also includes the problematization of technical systems, control, policies, and ideologies.

Over the years, each of these three areas has been included in discussions about the psychosocial work environment, to varying degrees and with differing emphases, and they have had varying degrees of impact in the field. At the end of the paper, we summarize our observations in relation to our three areas. The following section describes, in an approximately chronological order, the development of the concept of the psychosocial work environment and changes that have occurred along the way, as well as variations in the way the concept has been used and interpreted within Swedish working life. We will focus primarily on the first two areas- "health/illness" and "management and development." Some examples from the third area, "problematization," are also included, but this area is far too broad and varied to be addressed in such a brief discussion as this.

\section{A journey through time}

\section{Swedish occupational policy-early historical roots}

Before we attempt to dissect the development of and changes to the concept of the psychosocial work environment, we will briefly consider its early historical roots. In the beginning, the physical work environment was the center of attention. Johansson (1999) describes how Swedish occupational policy has its roots in England, Germany, and the United States. The English tradition is based on the humanism that has characterized the British upper class. In England, industrialization took place during the late 18th and early 19 th centuries, with major social problems as a result. For this reason, a number of laws were enacted during the early 1800s that limited child labor, for example, or at least the length of children's workdays in cotton factories to 12 hours a day. The German influence had a different starting point. Here, it was rather the fear of the growing labor movement and social democracy that drove developments. In the early 1880 s, a social welfare policy was adopted that included health insurance, accident insurance, and old age and disability pensions (Sund 1993). The common theme shared by the English and German development was faith in the state and the law as active instruments for shaping work environment policy. The American influence was of an entirely different nature. Here, there was no faith in the state or the law as bases for the establishment of work environment policy. The new industrialized society gave rise to major problems, however, particularly in the form of the rising number of accidents. The chosen solutions to this problem were largely based on local cooperation within individual businesses. These local initiatives were brought together in 1914 in the National Safety Council, which came to underpin the safety movement.

Sweden followed the English trend, albeit with a certain delay because of Sweden's later industrialization. In 1846, the minimum age for juvenile apprentices was set at 12 years. In 1852, night work was prohibited for children less than 18 years of age. The first true work environment law-the Factory Safety Act-was enacted in 1889. The Swedish Labor Inspectorate was established in 1890 (Danielson 1990). The right to 
appoint a safety officer was established in 1921 and safety committees were recommended in legislation from 1938 (Danielson 1990). Parallel with this legislated cooperation, voluntary cooperation was also established through what is now known as the Swedish Work Environment Association, which was formed in 1905. Voluntary safety committees existed from 1906 (Sund 1993). In summary, it can be seen that Swedish work environment policy came to rest on a strong welfare state based on the German model, with a comprehensive body of work environment legislation that resembled that of England. Inspired by the American example, local cooperation between businesses and employees concerning practical work environment initiatives was integrated into this legislation.

\section{Psychological considerations were an early feature}

Psychology marked its position within occupational research relatively early on through Hugo Münsterberg's book Psychologie und Wirtschaftsleben, which was translated into Swedish by the Federation of Swedish Industry in 1917. The Royal Swedish Academy of Engineering Sciences (IVA) also paid attention to these psychological issues, and in 1921, a human work science committee was formed that examined what it called "psychotechnical issues," in other words, how human work efforts could be economized and made more efficient. In 1924, the IVA published a paper entitled Work Psychology authored by Lundholm, in which he differentiated between psychotechnology, which addressed selection problems, and occupational psychology, which addressed external conditions affecting work efficiency (De Geer 1978). In terms of research, the period was primarily characterized by a more conscious establishment of the psychological perspective. Through the introduction of aptitude testing and selective testing, psychology also took on a more prominent position in working life. The first practical example of this shift was seen when the Sandvikens Jernverks AB used psychological testing as a basis for selecting personnel in 1928. The Swedish State Railways (SJ) also began to use psychological selection tests early on (ASF 1983). In 1944, the Institute of Applied Psychology was established as an independent division at Stockholm University. A similar institute, the Gothenburg Psychotechnical Institute, was also inaugurated in Gothenburg. From the outset, the institution's predominant activity was aptitude testing as a basis for vocational counseling and educational planning. Comprehensive research and development in methods for measuring skills and intellectual functions was conducted at both the institutes (ASF 1983).

\section{Taylorism}

American engineer Frederick Winslow Taylor conducted his first time studies in an engineering workshop at Midvale Steel Company, United States, in 1881. Taylor's theory (Taylor 1911/1972) can be summarized in two theses: 1) there exists one best way and 2) the right person for the right job. "There exists one best way" relates to Taylor's problem of gaining access to workers' professional skills in order to develop and apply work in a systematic way. He proposed conducting detailed time and motion studies, finding the best method and then teaching this to the workers. This was achieved through detailed 
job-sharing and standardized work stages in which each task was narrowly specialized with low qualification requirements. Teamwork and independent learning among workers were to be avoided, according to Taylor. Instead, it was important to instill employees with new values to get them to stop slacking off and to want to work according to "the best method." To achieve this, Taylor suggested a piece rate system, individual work, and continual monitoring by supervisors. Measurement and continual development of the work processes would lead to a streamlining of manual labor. Taylor's second principle- "the right person for the right job"- deals with methods for selecting workers who fit the given tasks. Taylor's writings contain many in-depth descriptions of targeted selection, including measuring the personal coefficient in order not only to employ those with the lowest coefficient (i.e., those who were not intelligent) but also to weed out lazy workers.

We can note that work psychology of this era was based on a view of people that we are not entirely comfortable with today. The human being was viewed as a machine and the idea was to adapt this machine to a particular task in order to increase organizational efficiency. In Scientific Management or "Taylorism," as it was known, many examples of this attitude can be found. Despite the fact that this was an accepted approach during this period, it did face criticism at the time. This was clearly seen in the very severe 1912 Senate hearing where Taylor was questioned, when both the economic efficiency and the social consequences of his system were challenged.

\section{Swedish Employers' Confederation and Swedish Trade Union Confederation collaborate on time and motion studies and work psychology}

Taylor's paper, The Principles of Scientific Management (Taylor 1911/1972), was translated into Swedish in 1913. Two prominent figures within the Swedish rationalization movement were Axel Engblom, who published a paper entitled Industrial Organization According to the Rational Management Principle (1922), and Tarras Sällfors, who was awarded a professorship in industrial economics and organization in 1939 and who, in the same year, published the book Work Studies within Industry (De Geer 1978). The IVA also involved itself in work-study issues and in 1934 published the paper Work Analysis and Time Studies (IVA 1934), which was a compilation of lectures on the subject.

The work environment was an area in which the social partners at labor market could easily cooperate. One example of this is the establishment of the Institute for Supervisory Training (ALI). At this school, both foremen and workers received training in economic, social, occupational health and work psychology issues (ASF 1983). In 1938, an industrial peace agreement known as the Saltsjöbadsavtalet was signed, which provided that the parties themselves were required to resolve their problems without involving the state. The agreement regulated how to negotiate about salaries and other working conditions and limited the right to undertake strikes or lockouts during the contract period. This cooperation would constitute an important part of what came to be known as "the Swedish model" and was deepened by the establishment of an additional cooperative agreement on work-studies in 1948 (Johansson 1988). At the same time, the Work Study Council was formed jointly by the Swedish Employer's Confederation and the Swedish Trade Union Confederation and was tasked with "tracking and promoting cooperation as relates to work-studies and the time and motion study councils' activities, as well as to otherwise work to ensure the sound and suitable organization of the work study function" (ASF 1983). 
Taylor's time and motion studies achieved their breakthrough in Sweden with the MTM method. MTM stands for "Methods Time Measurement" and is a system in which each manual work operation can be divided up into its basic motions, often down to the second level. Theoretically, using these basic motions, it is possible to design a task, determine a time, and establish the pay rate for a job. MTM was introduced in Sweden for the first time in 1951 at the Volvo Penta factory. During the latter half of the 1950s, and the following decade, the rationalization movement and work-study education blossomed in Sweden. In the 1950s, Gösta Rehn and Rudolf Meidner launched a new labor market policy, in which the trade union movement declared itself willing to promote sensible rationalization measures if businesses' excess profits were cut and taxed in return.

\section{Human relations}

An organizational psychology perspective was developed in parallel with the individualoriented psychological perspective. The theoretical basis for this was in the development of the Human Relations School of Management, which to a large extent constituted a criticism of Scientific Management, particularly of the idea of the replaceable human who requires monitoring and detailed instructions to be able to function in a production line. Organizational psychology is instead based on the notion that people have an inherent ability and desire to feel job satisfaction and to learn and develop both themselves and their work. What is needed is to create work environments that encourage this tendency.

Human Relations has its foundation in the classic Hawthorne experiments conducted by Elton Mayo at Western Electric's Hawthorne factory on the outskirts of Chicago in the United States (see, e.g., Mayo 1933). These experiments were conducted between 1924 and 1932. The basis for the experiments was the examination of the conclusions drawn by the human factors tradition, which claimed that deficiencies in the work environment in the form of poor working postures, tiring working hours, and poor physical environments (e.g., those with noise problems and inadequate lighting) had a negative impact on workers' performance. The researchers instead adopted the position that problems and unrest at the workplace had psychological causes or, more accurately, psychosocial causes. The experiments conducted revealed that there was an unknown factor that increased productivity, irrespective of working conditions. This "unknown factor" proved to be social relationships. Human Relations researchers drew the conclusion that work is a group activity and that peoples' need for recognition, security, and a sense of community is more important than material conditions in the workplace when it comes to productivity, work ethic, and motivation. Informal groups at the workplace exercise significant social control over the individual worker's productivity and attitudes.

The Hawthorne researchers' conclusions seem somewhat less obvious when they are examined more closely, however. Acker and van Houten (1974) demonstrated that the Hawthorne researchers used single-sex groups and treated these groups differently. For example, the young women in the Relay Assembly and Mica Splitting Rooms were, in addition to positive treatment, also exposed to manipulations and paternalistic control. They were given commands to increase their pace (and a raise in pay if they succeeded), not to talk or laugh while working, and underwent physical examinations once a month. 
If they protested, they were replaced. Some alternative conclusions may therefore be that the Hawthorne experiments not only provided new insight into the importance of social relations for the work environment but that they also proved that the psychosocial work environment can be used to exercise power, that is, to steer and control workers (Ahl 2006).

To this, we can add that the message that harmony and congenial management can almost be more important than a good, physical environment is not unproblematic. In the day-to-day work environment, it is of course important that there exists awareness that psychosocial aspects can be expressed in bodily and physical complaints, but as Thylefors (2008) reminds us, it is important that the work environment should not be "psychologized." Complaints about noise may actually be due to noise.

\section{The importance of work}

A contemporary study that even more clearly demonstrates how important work is to people is Marie Jahoda et al.'s (1933/1971) classic examination of unemployment and its consequences during the early 1930s in the Austrian community of Marienthal. The most important conclusion of the Marienthal study is that the function of work is not solely its manifest aspect, in other words, the obvious function that a wage plays in people's lives as relating to their survival and the opportunity to satisfy their material needs, but that work also plays an important role in people's social "survival." This applies not least of all to work's significance vis-à-vis a person's identity. The latter aspect relates to work's latent functions:

1. A time structure for the waking part of the day

2. Daily social contact with people outside of the nuclear family and experiences shared with these people

3. Participation in collective efforts that transcend personal goals

4. A social status and identity and

5. A regular activity

\section{Cooperating on the organizational perspective}

The Human Relations School of Management went on to develop industrial psychology, then organizational behavior, and-eventually-Human Resource Management. However, it took a strikingly long time before Human Relations gained a foothold within public discourse and research in Sweden. Its major impact came on the ideological level, where a more humane view of people was introduced, in contrast to Taylorism's more mechanical view of people. A more concrete mark of its influence was the introduction of personnel departments at companies during the 1940s and 1950s, now known as Human Resources departments.

Swedish industry also demonstrated its interest in research in the field by establishing the Centre for Business and Policy Studies (SNS) in 1948. SNS can be described as the starting point for a more social science-oriented view on working life, and it forged links with Sweden's foremost names within sociology, such as Edmund Dahlström and Joachim Israel. 
At approximately the same time, Torgny Segerstedt was awarded Sweden's first professorship in sociology. Collaboration between Segerstedt and Agne Lundquist was established, leading to a study, People in Industrialized Society, published in 1952.

Yet another player with a social science-based perspective arose in the form of the Swedish Council for Personnel Administration, established by the Swedish Employer's Confederation in 1952. The trade union cooperatives initially formed part of an advisory body (council) and from 1970 onward were included on the board. The organization was gradually expanded to include departments of industrial psychology and industrial physiology. Researchers Bertil Gardell, Göran Ekvall, Sigvard Rubenowitz, and Lennart Lennerlöf were associated with the council (ASF 1983).

\section{Motivation, needs, and values}

Human Relations was primarily developed further within the US Organizational Development (OD) tradition. The theoretical basis for this development was motivation research and action research. It is here that many of the ideas about the learning organization have their origins. One cornerstone in this development was Kurt Lewin's work on gestalt psychology, theories of personality, and group dynamics. In 1944, Lewin founded the Research Center for Group Dynamics at MIT in Boston in the United States and increasingly focused his studies on practical problems, social handling, and change processes. He named this practical research-in which researchers and practitioners working within organizations cooperated with one another- "action research."

Another important foundation was Abraham Maslow's and other psychologists' work on assumptions about individuals' motivation (see Maslow 1943). In Maslow's "needs hierarchy," "self-actualization" is the uppermost tier and a feature that is especially evident in contemporary society. Individuals' need for personal development began to be emphasized, and in time, an interest began to arise in how to create a climate or atmosphere within an organization that promoted its members' personal development and, thereby, improved their performance. One contemporary, complementary perspective came via Frederick Herzberg's theories about hygiene factors and motivation factors (Herzberg 1959, 1987). The factors that eliminate ill- health and dissatisfaction (hygiene factors) are not the same as those that create job satisfaction and commitment (motivation factors). Like the Hawthorne researchers, neither Maslow's nor Herzberg's models are undisputed. However, the models include a large portion of common sense, which makes them useful in matters relating to the psychosocial work environment, even today.

In the 1950s and 1960s, ideas about management by objectives (see Drucker 1954) were developed that are based on the idea that management's task is to create and communicate a vision and then, in consultation with staff, to formulate objectives related to their performance. This idea centers on giving personnel a large measure of independence and freedom. Instead of being controlled by managers, the staff was to practice "self-control." For this to work, Drucker explained, common values and standards must be established. In this way, managers can get employees to behave in the desired manner. Drucker recommended flat organizations divided into business areas, where each business area had its own business concept, so that employees would more easily feel a sense of responsibility for the whole unit. 
This approach increasingly revealed elements of systems thinking and discussions about the importance of values for both understanding and managing human behavior in organizations. One example of ideas about management systems is McGregor's $X$ and $Y$ theories (see McGregor 1960/2006. McGregor postulated that leadership in organizations must leave behind the authoritarian form, Theory $X$, in order to shift to a more participatory form of leadership, Theory $Y$. One important reason for this was that the level of education among the workforce had increased. This placed new demands on businesses' work organizations. It was important to be able to harness workers' increased capacity as well as to give them the opportunity to develop within their professions. One of the OD tradition's theorists, Chris Argyris (1957), advanced employees' personal commitment to an organization's underlying values as a key factor.

\section{The sociotechnical school}

Another part of the organizational perspective is what is known as sociotechnology. The concept was developed partly on the basis of analyses of the social system from the Human Relations School of Management, but integrated analyses of the technical system into these. Rational production flows constitute the nucleus of the idea. Added to this is a system theoretical approach, that is, that people, organizations, and technology both characterize and are characterized by their surroundings. Sociotechnical organizational theory was developed during the 1950s at the Tavistock Institute of Human Relations. Systematic education grew out of an analysis of the introduction of new technology in English coal mines (Trist and Bamforth 1951). Between the World Wars, mining was mechanized, and an earlier manual system was replaced by the semi-automated longwall method. Productivity did not increase as expected, however. The conclusion drawn by the researchers was that the technological interdependence between the different working shifts was not supported by a social system requiring integration and a holistic approach. Instead, the work organization and wage and status disparities between different work tasks had the opposite effect and contributed to a further fragmentation of the production system.

In a later phase of their work, the Tavistock researchers came into contact with a mine where the long-wall method worked very well. Productivity was higher than that of other comparable mines. The difference was that, at this mine, the workers themselves had created a work organization based on broader roles and that included work rotation both within and between work shifts. They had also succeeded in creating a social system that harmonized with the technical system, and the new system incorporated a high degree of autonomy. The Tavistock researchers had "discovered" the autonomous group.

Sociotechnology was primarily further developed in Europe. Even if inspiration for this development was taken from contemporary American OD research, European thoughts differed from American thoughts in several ways. Sociotechnology also addressed the technical system, with a clear focus on organization, while OD focused solely on changes in the social systems and more often concentrated on the individual. The sociotechnical school also introduced a different systems approach and proposed that workers' psychological needs should be placed within a larger context. Sociotechnical research was based on the work, the operation, and the technical system and was aimed at larger structural changes to the work organization in production, so that it better harmonized with the technology. 
Conversely, OD did not aim to introduce structural changes, but rather to improve relations between different organizational units. Another difference is that sociotechnology directed its attention toward the organization hierarchy base (i.e., production work, the work environments, and conditions for supervisors and workers), while OD primarily focused on leadership and the managerial tiers of the organization.

The sociotechnical school arrived in the Nordic region in the 1960s in the form of a series of experiments involving autonomous groups and product workshops in Norway. These experiments resulted in Thorsrud's and Emery's (1969) six psychological criteria for productive work:

1. The need for a degree of meaning and variety in work

2. The need to be able to learn while working and to be able to do so on an ongoing basis

3. The need to be able to make autonomous decisions about one's own area

4. The need for esteem, human understanding, and respect in the workplace

5. The need to see the connection between the work performed and the outside world and

6. The need to see that the work can be reconciled with hopes for the future

The results of the Norwegian experiments were promising and demonstrated that a changed work organization with increased worker influence can lead to increased productivity and job satisfaction (Thorsrud and Emery 1969).

\section{Critical perspectives}

Drawing inspiration from the Norwegian sociotechnical experiments, the equivalent Swedish research program, the Development Council Working Group for Research (URAF) conducted several experiments on new work methods in industry between 1969 and 1976. Unfortunately, these did not meet with success, probably largely due to the political turbulence surrounding industrial democracy, labor laws, and employee investment funds that prevailed at the time (Sandkull and Johansson 1996). Then came Sara Lidman's book Mine in 1968, contributing to a broad debate about the rationalization philosophies of the 1960s, an issue that was further emphasized through the major miners' strike that took place at Malmfälten during the winter of 1969/1970. Another famous book, The Art of Drilling People (Flordh et al. 1969), was a critique of the uncritical view of rationalization that prevailed at the time. A Marxist perspective began to develop within occupational research. This development should be understood against the backdrop of the spirit of the time. This was the time of the Cultural Revolution in China, the Prague Spring, massive student protests, and wildcat strikes.

Robert Blauner and Harry Braverman are examples of critical international researchers who came to influence the Swedish work organization research. In his book Alienation and Freedom (Blauner 1964), Blauner discussed how industrial workers' experienced their work and, above all, the technologization of the work process. One central theme of this work was alienation. Blauner measured the extent to which the workers experienced feelings of powerlessness, futility, isolation, and alienation. He discovered that the degree of alienation was greatest where production was dominated by an "assembly-line principle." 
Blauner also reached the conclusion that automation contributed to an integration of the workers and an increased feeling of control over the work, that is, that the introduction of an automated production contributed to a reduction in feelings of alienation. Blauner's research was introduced and developed by Bertil Gardell mainly in his doctorate thesis Production and job satisfaction - a social psychological study of industrial work in 1971 and was the beginning of a series of high-profile projects and studies on work organization and technology, particularly with respect to employee participation, empowerment, and health and safety (Gardell 1976, Gardell and Svensson 1981, Gardell et al. 1979). Harry Braverman, a noted critic of Taylorism, espoused a more negative view of the increasing degree to which technology was used in working life in his book Labor and Monopoly Capital: The Degradation of Work in the Twentieth Century (Braverman1974). According to Braverman, automation was one of the causes behind an increasingly degraded and routinized working life. Work organizations characterized by Taylorism were a second contributor to this trend. Braverman believed that these two factors led to a separation between the planning and execution of work, gave management a monopoly over planning, created a division of labor, and broke down the work process into specialized tasks. All of these factors combined gave management increased control over workers, their work, and their professional skills and knowledge.

Another early example of theories from the critical analyses of problems within the psychosocial work environment is the "workers' collective" and "collective cultures" (see Lysgaard 1961). Collective cultures are a kind of "defense system" that often is developed among employees at large workplaces where the working conditions and the work environment are experienced as problematic. A large group of subordinates within an organization who are approximately equal and who share problems is also a precondition for the development of such a culture. Their work assignments are often of a low rank within the organization. The collective culture compensates for the workers' low status and contributes to the affirmation and strengthening of their experiences and identities. The collective culture also offers the workers distance from "the others" (managers) and a "buffer" against the demands of the work, a kind of "free space" where they have control over the execution of the work, within certain limits. This acts as a free zone from feelings of being at a disadvantage, such as class-based subordination. Within collective cultures, the criterion of loyalty and strong standards of conformity regarding the way a worker should be and act develop, which do not always harmonize with what is productive and profitable for the company, or even what is best for the workers themselves (Fältholm 1998). Since, to a large extent, collective cultures are built on the basis of identification, similarity, and homosociality, the strongest collective cultures develop in gender-homogeneous workplaces (Lindgren 1985, 1999). Workers who do not follow the behavioral and identity norms are excluded (e.g., women workers in maledominated workplaces) and may experience psychosocial work environment problems.

Similar conclusions can later be found in Rosabeth Moss Kanter's book Men and Women of the Corporation (1993/1977). Kanter focuses on the structural conditions within work organizations that create different psychosocial work environments for women and men. Her point of departure is that women and men are essentially alike, but that their disparate positions and conditions within the organization either force them or construct them in such a way that they act as though they were different. The organization's structure, culture, and values create boundaries that limit the scope of the opportunities that members of the organization have to work within. Kanter calls 
these "opportunity structures" and believes that organizations often provide different opportunity structures for men and women. She explained this primarily through type of work/position, but also through the relative number of women and men. Kanter's theory about the significance of the relative number is that groups or organizations with uneven gender distributions give rise to certain behavioral patterns, strategies, and conceptions of the minority group. Kanter argues that it is their small numbers, rarity, and visibility, rather than their femininity, which determine the conditions for women within male-dominated organizations. This minority situation generates structural effects and Kanter highlights three types of such effects: contrast, visibility, and stereotyping. Our point is that these create psychosocial work environment problems for both the majority and the minority and therefore Kanter's theories, as well as other critical perspectives, contribute to the understanding of psychosocial work environment.

\section{Sociotechnology - a base for both employers' and trade unions' ideas}

In Sweden, the first half of the 1970s was characterized by a great interest in work environment issues. This interest was also seen in the explosion of work environment research, particularly achieved through the creation of the Department of Occupational Medicine at the National Board of Occupational Safety and Health and the Swedish Work Environment Fund in 1972. Human Work Science was established as a department at Luleå University of Technology in 1973 as part of an effort to include human work science in programs at all technical universities in Sweden, a successful reform even though it took more than ten years to complete.

During this period, employers and the trade union movement began to take different paths with regard to the development of the work organization. The trade union movement focused on industrial democracy and, in 1976, succeeded in pushing through a legal regulation in support of increased workers' participation. This clearly contributed to expanding the concept of the work environment to include a democratic work organization (Simonson 1989). The Swedish Employers' Confederation (SAF) began its own research in which the classical example was the Volvo Kalmar factory, which came online in 1974. This factory tested new technological solutions in designing workplaces and the factory's layout so that it would follow sociotechnical ideas, such as flexible assembly steps, flow organization, longer cycle times, a deepening and expansion of work assignments, and group work for the employees. SAF developed these ideas into a vision of tomorrow's technology and work organization that went by the name New Factories (Agurén and Edgren 1979). The trade unions also drew inspiration from sociotechnology when they formulated their vision for the work of the future, a vision that was dubbed Good Work (see Metall 1985).

In the 1980s, Swedish industry was confronted with increased demands for customization, delivery assurance, service, and quality. This required new technical and organizational solutions and a trend toward a more flexible productive apparatus, often in combination with decentralized management. The solutions were based on technology, work organized in groups, skilled and independent work tasks, and a skilled labor force (Helgeson and Johansson 1992). These were solutions that harmonized well with sociotechnology and the unions' demands for the implementation of "Good Work," which was being raised at the same time (Berggren et al. 1987). The Volvo Uddevalla factory 
established during the mid- and late 1980s was the result of a sociotechnical organization of production (Berggren 1990, Ellegård et al. 1991, Engström et al. 1998). Ideas about the importance of industrial workers' skills development and their influence in the workplace were allowed to shape the design of the production system. This thinking was combined with capital rationalization in the form of reduced stock holding, an early version of just-in-time production, and lean production. We can see this as a new consensus between employers and trade unions. Employers not only accepted the group work requirement but also took the initiative to implement it themselves.

The majority agreed that the future would involve some kind of group-organized production in which workers were not machine-bound and where work was enriched through a far-reaching decentralization of what had previously been "white-collar tasks." Similar ideas about change processes with their basis in production work, human-technology interaction, holistic perspectives, and ideas of both productive and stimulating work existed within Swedish work environment research (Berggren et al. 1987, Bergman 1995, Lindhal and Broms, 1989). One example of this sociotechnical spirit of the period is the Master of Science in engineering program, Industrial Work Environment (now called Industrial Design Engineering), that began at Luleå University of Technology in 1984. We can conclude that during this period, skills development, worker influence, and involvement were more clearly introduced as elements in the discussion on work organization, and thereby also into the understanding of the psychosocial work environment.

\section{The demand-control-support model}

One central theory of the relationship between workers' health and their influence on and participation in the workplace is known as the Karasek-Theorell Demand-ControlSupport-model (Karasek and Theorell 1990). The model was developed in the late 1970s and has been continually refined since then. It is often used in spite of the fact that it does not cover all aspects and does not fit all types of work, perhaps due to its simplicity and measurability. The model is based on the parameters demand, control, and support. "Demand" refers to how hard a worker works (large workload, pressed for time, difficult work tasks, and role conflicts). "Control" refers to an individual's own control over the situation, the worker's freedom to make decisions and influence what will be done, when, and how. "Social support" includes practical and emotional help from managers and workmates, a kind of buffer. If demands are too great, irregular, or difficult to understand and the employee has difficulty controlling them and lacks support from others, then work stress will increase. If workers find themselves in such a "tense situation" over a long period of time, then it will also affect their health. Conversely, a passive work situation can also be problematic, leading to understimulation, thereby contributing to an unmotivated labor force, which, in the long term, can also be damaging to health (Karasek and Theorell 1990).

This model has not been altogether simple to apply to modern working life, however. For example, it has been shown that an "attractive work situation"-work with a high degree of personal control-can also cause ill health, despite the fact that the model suggests that this should constitute a positive situation from a health standpoint. Such paradoxes can be better explained if they are supplemented with an organizational perspective in which the parameters demand, control, and support have their origin in the organization, rather than in the individual (Härenstam 2008). Rasmussen (1999) 
uses the metaphor "seductive and greedy" to describe an organization that, admittedly, is "good" (freedom to act and interesting, stimulating, and autonomous work tasks), but that places responsibility on individuals and that demands increasing amounts of overtime, attention, energy, and effort from these individuals. Theorell (2003) also raises the issue of whether there is an optimal level for influence and self-determination. Similar thoughts are found in the "vitamin model" (Warr 1994), which likens psychological factors in working life to vitamins. In the case of most factors, a lack can be damaging. Certain factors cannot exist in too great a measure, but do not generate any positive effect above a certain level. For some factors, in certain circumstances, overdoses can be damaging. Thylefors (2008) writes that the vitamin model has met with mixed reactions. Nonetheless, it does demonstrate the need for a holistic approach when it comes to the psychosocial work environment.

\section{Learning and dialogue}

In the 1970s, American OD researchers Argyris and Schön (1978) continued working and developed theories on what guides an individual's behavior. The processes in which the individual chooses to act in accordance with their current theory of action, or chooses to modify the basic values and create a new theory of action, were viewed by Argyris and Schön as learning processes. In the 1980s, this theory was supplemented with elements taken from democratic theory (Gustavsen 1990). There was an increased emphasis on broad participation and dialogue. People at workplaces were to create solutions to the workplace's problems themselves. This theoretical line was further developed during the 1980s and 1990s in theories of learning and corporate culture.

A number of large cross-disciplinary research programs were started in Sweden in the 1980s, funded by the Swedish Work Environment Fund or the Swedish Agency for Economic and Regional Growth: the Development Program for New Technology, Work Organization and Work Environment (1982-1987), Management, Organization, Workers' Participation (LOM) (1985-1990), and the Learning Program (1990-1996). These programs entailed a breakthrough for ideas concerning continual skills development, lifelong learning, learning organizations, and richer work content. Lifelong learning was first mentioned in the Development Program. The LOM program concentrated on development work at businesses, with a focus on cooperation and dialogues between employees and management (Lundin 1988). The program was based on action research and democratic dialogue (Gustavsen 1990). The Program for learning organizations, the Learning Program was a joint initiative by labor market stakeholders and can be seen as a direct continuation of the LOM program. It was built on the idea of the "learning organization" and organizational preconditions that stimulate and support learning.

The most important thing a learning organization should do, according to Ellström (2001), is to give all employees the opportunity to act and learn at multiple levels. Action should not be limited to the level of routines or rules because this also limits opportunities for creativity and development-oriented learning. Routines that are too engrained and an emphasis on adaptive-oriented learning are obstacles to development-oriented learning and to renewal. Organizations must balance the force of development logic and production logic in their operations. It is a case of "the two in tandem." This requires that the workplace itself and work tasks are concrete learning environments. In current 
research, the manager's responsibility to arrange self-organization and learning is also emphasized. The skills-bearing relationships of people are seen as important perspectives from which to develop both innovative and effective organizations and sustainable occupational health for staff (Backström and Söderberg 2007).

These perspectives are quite typical of the Swedish working life research. A Nordic research team (Sørensen et al. 2012) has analyzed Nordic research tradition and they distinguish between two dimensions: seeing the workers as subjects (to do research with) or objects (to do research about) and seeing workers as individuals or as a collective. According to the research team, the Nordic approach gives clear priority to workers as subjects acting in and through the collective group.

\section{The 1990s-politicians take the lead}

A more political element also emerged in Sweden during the late 1980s. In conjunction with the election campaign of 1988, the Social Democratic Party promised to improve the 400,000 worst jobs in the country. The result was that the government appointed a Government Commission on Work Environment that would draw up guidelines for the new work environment policy. The commission presented its recommendation in 1990, in which it was suggested that employers should take on increased responsibility for the work environment and rehabilitation (Arbetsmiljökommissionen 1990). Another outcome was the transition from a direct work environment view to a systematic view, that is, that the Labor Inspectorate should check that the employer had a satisfactory system in place to manage work environment-related matters.

At the same time as the commission was carrying out its work, a debate about large profits in the business sectors was occurring. The political will to keep down wage levels in order to fight inflation also existed at the time. Ultimately, the solution was cooperation between the Social Democratic Party and the Centre Party, in which they forced businesses to contribute a portion of their profits to a central fund for the development of the work environment and rehabilitation. The Swedish Work Life Fund began in 1990 and ultimately controlled a very large sum used to realize some of the Government Commission on Work Environment's objectives, namely support for businesses' OD and improvements to work environment. This entailed a powerful supplement for the development of Swedish working life. The majority of projects were also connected with some form of professional development, where the concept of "learning organizations" was central. The Work Life Fund was closed in 1995 and was replaced by the European Social Fund's Objective 4 Program (1996-2000), which was even more focused on learning and skills development.

\section{Modern organizational models-a new kind of consensus, but also new work environment problems}

This investment in learning was played down after some years, however. The 1990s were instead very much characterized by the deep recession that occurred in Sweden at the start of the decade, which affected both the public and private sectors. The recession brought with it high unemployment, increased polarization, and deeper social divides. Industrial concerns implemented drastic measures in order to reduce their costs. Outsourcing, 
downsizing, and "lean organization" became commonly used terms, part of the inspiration for which came from the concept of "lean production" as presented in the book The Machine that Changed the World (Womack et al. 1990). But this development was met with criticism; understaffed organizations can cause problems for companies as development initiatives become stifled because the cuts strip them of both skills and resources. Employee health and well-being can also be compromised and there is a risk of reduced motivation and of reduced opportunities for learning. The second phenomenon that arose during this period was that short-term positions and the number of nonpermanent positions increased, employment contracts became more individual, wage dispersion increased, and the power of the unions diminished (Aronsson and Sjögren 1994). This was combined with the reappearance of certain elements from Taylorism (e.g., monitoring, micro-management, measurement, standardization, and the idea that there existed one best way) under new names, particularly in concepts like "lean production," "balanced scorecard" (Kaplan and Norton 1993), and "knowledge management" (Sanchez and Heene 1997). The number of short-cycle and repetitive work tasks increased, leading to monotonous work with uneven physical loads (Westgaard and Winkel 2011). If "continual improvement" is used to make work tasks increasingly simple to make them faster to perform, then skill level is reduced rather than increased (Ellström 1996). A focus on order and standardization means that workers' autonomy and the extent to which they make their own decisions are significantly reduced. Lean production and similar concepts contain tools for establishing standardized work routines, which risk creating feelings of exchangeability and dequalification among workers (Ellström 2000).

Even so, learning and participation continued to exist in parallel with this shift, albeit in another form. During the 1990s, Human Relations, American OD, and leadership ideology underwent a clear renaissance within the US and Japanese management concepts, which quickly spread across the western world in the form of an organizational trend (Abrahamsson 2002, Björkman 2002). The importance of leadership, harmony, dialogue, positive group norms, values, motivation, learning, and corporate culture in the management of both the organization and the individual was promoted in concepts such as “Total Quality Management" (Deming 1982, Feigenbaum 1961), "the boundary-less organization" (Ashkenas et al. 1995), "the learning organization" (Senge 1990), and "the individualized organization" (Ghoshal and Bartlett 1997).

At the same time as the modern organizational concepts gained increasing adherence in working life during the 1990s, the number of Swedes on sick leave increased. This coincided with employees in county councils, municipal governments, and industry experiencing an increased workload and reduced opportunities to influence different circumstances in their work during this period (Gellerstedt 2008, Theorell 2006). Especially tangible was the trend toward poorer opportunities for control among women employees working for county councils and municipal governments (i.e., in health care and schools) and in commerce, service, and industry. At the same time as these opportunities to exercise control were waning, the physical and psychological demands in working life increased, and there were fewer opportunities for recuperation. Among the problems of the 1990s, Theorell (2003) notes an increased silence (i.e., the sense that it was not possible to complain about work environment problems), false democracy, and large and almost panicky changes to work organization.

During this period, the political debate about work environment and work organization waned in intensity. Trade unions focused more on unemployment and labor 
legislation. At the same time, employers advanced their positions and actively worked to develop a new work organization by implementing the new management concepts, among which "balanced scorecard" and "lean production" were the most influential, even experiencing a renaissance during the 2000s (Johansson and Abrahamsson 2008). Trade unions chose to cooperate and this new understanding was not, as previously, built on agreements and contracts, but was instead a tacit consensus shaped by the economic crises of the 1990s and the dream of growth of the early 21 st century. The arguments used often referred to the market that, in one way or another, had forced the concrete action.

\section{What is the situation today?}

This new consensus in Sweden appeared to have limited need of work environment and work life-related research (Johansson 2004). The closure of the National Institute for Working Life in 2006 was an administrative, and in some ways political, action but also meant a reduction in the sector's research resources. Another trend was that work life research in many Swedish universities was-more obviously than previouslyamalgamated with other subjects. While integration certainly is mainly good, it also has had the effect that work environment research became more difficult to find, and perhaps also more difficult to develop. This is also due to the absence of a platform for interdisciplinary communication and national and international cooperation. All in all, the past decade has resulted in reduced visibility and a lower status for the field, which might also have consequences for working life. Knowledge about the work environment is more easily "forgotten" and becomes more difficult to integrate into production and organizational development. The Swedish public debate on working life in recent years has primarily revolved around spoiled and lazy people and how to avoid cheating within the social insurance system.

Even if such cheating is an issue that must be addressed, there are still many workplaces that are highly problematic when it comes to employment conditions and work environment (Brännmark et al. 2012, Hasle et al. 2012, Westgaard and Winkel 2011). At these workplaces, there seems to be a view that people can be used like machines. Other worrying situations are also emerging, such as the revival of the assembly line and Taylorism in both the industry and the service sectors. We see old work environment problems appearing in new contexts, such as in new industries and occupations. However, new types of work environment problems are also emerging as a result of cost cutting, globalization, new technology, and the modern lifestyle (Björkman 2002, Johansson and Abrahamsson 2007, Thompson and Warhurst 1998). Even though knowledge about what good work environments are and how they can be created is both extensive and accessible, it seems at times that the trend is heading in the exact opposite direction or that the wheel is being reinvented. This is a case of almost 100 years of knowledge being forgotten. And this leads to the impression that the pace of development is very slow.

By the same token, we can also discern positive tendencies in the form of increasing productivity and improved working conditions (Brännmark et al. 2012, Hunter 2008, Saurin and Ferreira 2009) and also in research (e.g., centers of excellence in human work science supported by FAS and other major financing initiatives) and also in the 
Swedish Forum for Research in Working Life (FALF) and similar networks, both old and new. Other positive trends include that many of the latest calls for projects by large national research financiers include requirements for interdisciplinary science, where work science is seen as a natural component. Within our own research sphere, we have also seen a number of good examples where the work environment perspective has been included in major interdisciplinary projects within engineering faculties. The European structural funds-the Regional Development Fund and the Social Fund-have been important players with regard to organizational development, participation, influence, and workplace learning, even if the focus on regional development, new job openings, and the individual and on those outside of working life is unfortunately shifted away from the work organization, that is, away from the psychosocial work environment.

Other trends include what appears to be quite a large part of Swedish working life is moving toward a positive "self-cleaning" (that is, adopting the view that injuring people at work is intolerable and that the work environment is a natural part of a trademark) (NCC 2012, Prevent 2012). In recent years, we have also seen the clear development of a "Nordic variety" of the use of "lean," a variety that entails a recreation of ideas about holistic approaches, workplace design, participation, influence, and autonomous groups (Johansson and Abrahamsson 2009). This is also a strain that has been greatly influenced by theories about the learning organization, workplace learning, and creativity among all employees. The concrete content of the new consensus that has developed between stakeholders is a new work environment concept that even more clearly includes organizational and professional development and the psychosocial work environment. Yet another positive trend is that work environment issues and this holistic view are making their way onto the political agenda (Helmersson Olsson et al. 2012/2013, Olovsson 2008/2009). They are seen as strategic instruments for development both inside businesses and at the community level.

\section{Concluding reflections}

It has been difficult to try to describe this "journey through time" because there has been neither a linear line of development nor a homogeneous story about the psychosocial work environment. Instead, the history of the psychosocial work environment has involved parallel and simultaneous processes and shifts between perspectives.

In the beginning of our article, we presented three different areas or perspectives that interacted with each other: "health/illness," "management and development," and "problematization." The first perspective, "health/illness," dealing with health problems and stress symptoms, has been the dominant in our journey through time. The perspective has been modernized, but basically its importance has been rather stable over time. The second perspective, "management and development," has led to a broadening of the concept of psychosocial work environment by giving organizational explanations and by seeing workers as individuals who can independently act both for and against the company's intentions. However, we argue that "management and development" can also be seen as a perspective by its own by pointing to the potential in managing organizations, groups, and individuals. In our journey through time, it is fairly easy to identify quite a number of shifts in this area, between two approaches, one based on a rational-instrumental philosophy and another on a normative-institutional philosophy 
(Røvik 2000, Tengblad 2006). Early work psychology, Taylorism, lean production, and everything else based on the idea that people and organizations are best managed using technology, measurement, systematics, centralization, standardization, specialization, and rules and by issuing orders are often placed within the framework of rational philosophy. Human Relations, motivation theory, management by objectives, the learning organization, and everything else that is based on the idea that people and organizations are best managed using norms, harmony, participation, corporate culture, and common values and symbols can be placed inside the framework of normative philosophy. Today, it is the latter tradition that is predominant, especially in everyday practice, where a popular feature is the concept of "empowerment," highlighting the individual skills and ability to make their own decisions. A central part of this is learning-both individual and collective-as well as other organizational perspectives. On the other hand, the rational-instrumental approach is by no means dead, but has rather been given new energy by the heavy influence of lean production and similar concepts.

In our journey through time, we included some theories from the third perspective, "problematization," and from these we can deduce a discussion that maintains that both rational-instrumental approach and the normative-institutional approach are wrong (and right). By this, we are reminded that empowerment, leadership, and attitudes are not enough. In order to stimulate learning, innovation, and a good psychosocial work environment, concrete changes to the organization, workplace, and technology must also occur. Neither is it sufficient simply to invest in new technology or new management systems. These things, in themselves, are not guaranteed to change efficiency or working conditions, either positively or negatively. In order to ensure positive development, we must adopt a more sociotechnical approach where the human, work environment, and the organization of work, both formal and informal, must also be included. Moreover, the concept of empowerment has no meaning unless one takes into account how the real power is distributed at the workplace. Another related discussion from the problematization perspective is that management by means of culture and common values builds on harmony and unity in the organization and conceals disparities in power and opportunity both inside and outside the organization. There is probably a risk that when abstract (and positive) things like attitudes, culture, dialogue, and learning stand in focus, more concrete aspects of the work environment become hidden (Blumberg 1971, Svensson 2004). Such concrete aspects may be wages, physical work environment, and work content but also many aspects of psychosocial work environment, like influence and gender stereotypes (Abrahamsson 2002).

Of course, problematization is included in the two first perspectives, but we argue that "problematization" can be seen as a perspective of its own as it can contribute to additional understandings of psychosocial work environment, to why it is so difficult to implement improvements to the work environment, why certain contexts develop negatively, and why knowledge about good work environments is not utilized. We believe that more emphasis on problematization will lead to better analysis and by extension hopefully breaking the current inertia.

We knew that basic elements of a sustainable, innovative, efficient, and profitable work organization, as well as of a well-functioning economy and society, are that workers' health is improved by being at work, they enjoy being there, and they are able to exercise influence and learn and develop together in the workplace. We think it is time to create a new vision for the work environment, a vision where we do not focus on illness and psychosocial work 
environment problems, but instead a vision of where we see work as a source of health and wellness. The work should be an important component of developing ourselves as creative people and allow us to enjoy our otium as healthy and intellectually active people. The challenge for the future is to develop this perspective in both theory and practice. Let us hope that the 21 st century will be described as "one hundred years of improvements." There are signs that indicate that this may well be the case.

\section{References}

Abrahamsson, K., et al. (2003). Friskfaktorer i arbetslivet. Stockholm: Prevent.

Abrahamsson, L. (2002). Restoring the order: Gender segregation as an obstacle to organisational development. Applied Ergonomics, 33(6): 549-557.

Acker, J. and van Houten, D. (1974). Differential recruitment and control: The sex structuring of organizations. Administrative Science Quarterly. 19(2): 152-163.

AFS (1980). Psykiska och sociala aspekter på arbetsmiljön, Stockholm: Arbetarskyddsstyreldens författningssamling AFS 1980: 14.

Agurén, S. and Edgren, J. (1979). Annorlunda fabriker-Mot en ny produktionsteknisk teori. Stockholm: Svenska Arbetsgivareföreningen.

Ahl, H. (2006). Motivation in adult education: A problem solver or a euphemism for direction and control? International Journal of Lifelong Education, 25(4): 385-405.

Arbetsmiljökommissionen (1990). Arbete och hälsa: betänkande av Arbetsmiljökommissionen. Statens offentliga utredningar 1990: 49. Stockholm: Allmänna förlaget.

Argyris, C. (1957). Personality and Organization. New York, NY: Harper.

Argyris, C. and Schön, D. (1978). Organizational Learning: A Theory of Action Perspective. Reading, MA: Addison-Wesley.

Aronsson, G., Hellgren, J., Isaksson, K., Johansson, G., Sverke, M., and Ingemar, T. (2012). Arbets- och organisationspsykologi: Individ och organisation i samspel. Stockholm: Natur \& Kultur.

Aronsson, G. and Sjögren, A. (1994). Sambällsomvandling och arbetsliv. Omvärldsanalys inför 2000-talet. Solna: Fakta från Arbetslivsinstitutet.

ASF (1983). Beteendevetenskaplig arbetsmiliöforskning-Historisk bakgrund och utveckling i Sverige. Stockholm: Arbetarskyddsfonden rapport 1983: 6.

Ashkenas, R., Ulrich, D., Jick, T., and Kerr, S. (1995). The Boundaryless Organization. San Francisco, CA: Jossey-Bass Publishers.

Backström, T. and Söderberg, I. (2007). Organiseringens samtal. Om hållbar utformning av organisation och rum. Arbetsliv i omvandling 2007: 06.

Berggren, C. (1990). Det nya bilarbetet (The Volvo Trajectory). Arkiv förlag.

Berggren, C., Ellegård, K., and Holmgren, A. (1987). Den goda fabriken. Förslag till checklista. Projektrapport. Stockholm: Arbetsmiljölaboratoriet.

Bergman, P. (1995). Moderna lagarbeten. Lund: Arkiv förlag.

Björkman, T. (2002). Den långlivade taylorismen. In Abrahamsson, Kenneth et al. (eds.) Utbildning, kompetens och arbete. Lund: Studentlitteratur.

Björkman, T. (2003). Management-en modeindustri. In Sandberg, Åke (ed.) Ledning för alla? Om perspektivbrytningar i företagsledning. 4: e upplagan. Stockholm: SNS Förlag.

Blauner, R. (1964). Alienation and Freedom. Chicago: University of Chicago Press.

Blumberg, P. (1971). Företagsdemokrati i sociologisk belysning. Stockholm: Rabén \& Sjögren.

Brännmark, M., Eklund, J., Håkansson, M., and Vogel, K. (2012). Belastningsergonomiska studier utifrän ett produktions- och systemperspektiv-interventioner, verksambetseffekter och konsekvenser. Stockholm: Arbetsmiljöverket. 
Braverman, H. (1974). Labour and Monopoly Capital. New York, NY: Monthly Review Press.

Danielson, G. (1990). Från yrkesfarelag till arbetsmiljölag. In Ekström, E. and Hall, I. (eds.) Från yrkesfara till arbetsmiljö. Arbetarskyddsstyrelsen.

De Geer, H. (1978). Rationaliseringsrörelsen i Sverige. Stockholm: SNS.

Deming, W. E. (1982). Out of the Crisis. Cambridge, MA: MIT Press.

Drucker, P. (1954). The Practice of Management. New York, NY: Harper \& Brothers.

Ds (2008: 16). Arbetsmiliön och utanförskapet. Diskussionspromemoria från regeringen.

Ellegård, K., Engström, T., and Nilsson, L. (1991). Reforming Industrial Work. Principles and Realities in the Planning of Volvo's Car Assembly Plant in Uddevalla. Stockholm: Arbetsmiljöfonden.

Ellström, P.-E. (1996). Arbete och lärande-förutsättningar och hinder för lärande i dagligt arbete. Stockholm: Arbetslivsinstitutet.

Ellström, P.-E. (2000). Lärande och kompetensutveckling i magra organisationer: problem och möjligheter. In Lennerlöf, Lennart (ed.) Avveckla eller utveckla? En antologi om verksambetskonsekvenser i magra organisationer. Stockholm: Rådet för arbetslivsforskning.

Ellström, P.-E. (2001). Integrating learning and work: Problems and prospects. Human Resource Development Quarterly, 12(4): 421-435.

Engblom, A. (1922). Industriell organisation enligt den rationella arbetsledningens princip. Uddevalla.

Engström, T., Jonsson, D., and Medbo, L. (1998). The Volvo Uddevalla plant and interpretations of industrial design processes. Integrated Manufacturing Systems, 9(5): 279-295.

Fältholm, Y. (1998). Work, Cooperation and Professionalization. A Multiple Case Study. Doktorsavhandling, Institutionen för Arbetsvetenskap, Luleå tekniska universitet.

Feigenbaum, A. V. (1961). The Quality Control. New York, NY: McGraw-Hill.

Flordh, C., et al. (1969). Konsten att dressera människor. Stockholm: Prisma debatt.

Gardell, B. (1971). Produktionsteknik och arbetsglädje-en socialpsykologisk studie av industriellt arbete. Stockholm: PA-rådet.

Gardell, B. (1976). Arbetsinnehåll och livskvalitet. Stockholm: Prisma.

Gardell, B. and Svensson, L. (1981). Medbestämmande och självstyre. Stockholm: Prisma.

Gardell, B., Gustafsson R., Brandt C., Tillström I. and Torbörn I. (1979). Sjukvård på löpande band. Stockholm: Prisma.

Gellerstedt, S. (2008). Trender i arbetsmiliön 2007-klass och kön. Stockholm: LO.

Ghoshal, S. and Bartlett, C. A. (1997). The Individualized Corporation. A Fundamentally New Approach to Management. New York, NY: Harper Collins.

Gustavsen, B. (1990). Vägen till ett bättre arbetsliv. Arbetslivscentrum, Stockholm.

Härenstam, A. (2008). Organisational approach to studies of job demands, control and health. SJWEH, 6, 144-149.

Hasle, P., Bojesen, A., Langaa Jensen, P., and Bramming, P. (2012). Lean and the working environment: A review of the literature. International Journal of Operations \& Production Management, 32(7): 829-849.

Helgeson, B. and Johansson, J. (1992). Arbete och yrkesutbildning-En studie av verkstadsindustrins behov av kvalificerad arbetskraft, i Halvorsen, Olsen, Det kvalifiserte samfunn?, Oslo: Gyldendal.

Helmersson Olsson, C. et al. (2012/2013). En god arbetsmiljö för ett längre arbetsliv. Sveriges riksdag: Motion 2012/13: A339.

Herzberg, F. (1959). The Motivation to Work. New York, NY: John Wiley and Sons.

Herzberg, F. (1987). One more time: How do you motivate employees? Harvard Business Review, 65(5): 109-120.

Hunter, S. L. (2008). The Toyota production system applied to the upholstery furniture manufacturing industry. Materials and Manufacturing Processes, 23(7): 629-634. 
Ingenjörsvetenskapsakademin (1924). Arbetspsykologi. Meddelande nr. 36, Stockholm.

Ingenjörsvetenskapsakademin (1934). Arbetsanalys och tidsstudier. Meddelande nr. 106, Stockholm.

Jahoda, M. (1941). Some socio-psychological problems of factory life. British Journal of Psychology, 31: 191-206.

Jahoda, M., Lazarsfeld, P. F., and Zeisel, H. (1933/1971). Marienthal: A Sociography of an Unemployed Community. London: Tavistock.

Johansson, J. (1988). Facklig syn på ny produktionsteknik. Forskningsrapport 1988: 01, Luleå: Tekniska högskolan.

Johansson, J. (1999). A survey of Swedish work environmental and occupational research during the twentieth century. Human Factors and Ergonomics in Manufacturing, 9(4): 1-14.

Johansson, J. (2004). Den tandlösa tigern-den svenska arbetsmiljöforskningen som förändrande kraft, i Johansson, Bo, Frick Kaj, Johansson Jan, Framtidens arbetsmiliö- och tillsynsarbete, Lund: Studentlitteratur.

Johansson, J. and Abrahamsson, L. (2007). Lean production and the future of "The good work". Paper at the Swedish Production Symposium 2007, 28-30 August 2007, Göteborg, Sweden.

Johansson, J. and Abrahamsson, L. (2008). The organization of production and work. In Boghard, Mats, et al. (eds) Work and Technology on Human Terms. Stockholm: Prevent.

Johansson, J. and Abrahamsson, L. (2009). The good work-A Swedish trade union vision in the shadow of lean production. Applied Ergonomics, 40(4): 775-780.

Kanter, R. M. (1993/1977). Men and Women of the Corporation. New York, NY: Basic Books.

Kaplan, R. S. and Norton, D. P. (1993). The Balanced Scorecard. Boston, MA: Harvard Business School Press.

Karasek, R. and Theorell, T. (1990). Healthy Work: Stress, Productivity and the Reconstruction of Working Life. New York, NY: Basic Books.

Lidman, S. (1969). Gruva. Stockholm: Bonniers.

Lindgren, G. (1985). Kamrater, kollegor och kvinnor-en studie av könssegregeringsprocessen i två mansdominerade organisationer. Doctoral thesis. Umeå: Umeå University.

Lindgren, G. (1999). Klass, kön och kirurgi—relationer bland vårdpersonal i organisations förändringarnas spår. Malmö: Liber.

Lindhal, P. and Broms, G. (1989). Engineering design methods applied to steelmaking. In Törnqvist, Anders and Ullmark, Peter (eds). When People Matter. Nordic Industrial Architecture \& Engineering Design. Swedish Council for Building Research.

Lundin, M. (1988). Från byråkrati till deltagardemokrati. Om perspektivförskjutningar $i$ arbetsvetenskaplig och organisationspsykologisk forskning. LOM-programmet. Stockholm: Arbetsmiljöfonden.

Lysgaard, S. (1961). Arbeiderkollektivet: en studie $i$ de underordnedes sosiologi. Oslo: Universitetsforlaget.

Maslow, A. H. (1943). A theory of human motivation. Psychological Review, 50(4): 370-396.

Mayo, E. (1933). The Social Problems of an Industrial Civilization. New York, NY: McMillan.

McGregor, D. (1960/2006). The Human Side of Enterprise. New York, NY: McGraw-Hill.

Metall (1985). Det goda arbetet. Huvudrapport frän programkommittén om industriarbetets värde och villkor presenterad vid Svenska Metallindustriarbetareförbundets kongress, 1-7 September 1985. Stockholm: Metall.

Münsterberg, H. (1917). Psykologi och näringsliv. Uppsala: Industriförbundet.

NCC (2012). Noll olyckor är målet, Arbetsliv nr. 2012: 6. 
Olovsson, F. (2008/2009). Strategi för nollvision på arbetsmiljöområdet. Sveriges riksdag: Motion 2008/09: A258.

Prevent (2012). Arbetsmiliörappårt 2012—chefer och skyddsombud om arbetsmiliön i framtiden. Stockholm: Prevent.

Rasmussen, B. (1999). Dehierarchization-Reorganizing Gender? Doctoral thesis. Trondheim: NTNU.

Røvik, K.-A. (2003). The secrets of the winners: Management ideas that flow. In SahlinAndersson, K. \& Engwall, L. (eds). The Expansion of Management Knowledge: Carriers, Flows, and Sources. Stanford, CA: Stanford University Press.

Sällfors, T. (1939). Arbetsstudier inom industrin. Stockholm.

Sanchez, R. and Heene, A. (1997). Strategic Learning and Knowledge Management. New York, NY: Johan Wiley \& Sons.

Sandkull, B. and Johansson, J. (1996). Från Taylor till Toyota. Lund: Studentlitteratur.

Saurin, T. and Ferreira, C. (2009). The impacts of Lean production on working conditions: A case study of a harvester assembly line in Brazil. International Journal of Industrial Ergonomics, 39: 403-412.

Segerstedt, T. and Lundquist, A. (1952) Människan i industrisambället. Stockholm: SNS Förlag.

Senge, P. (1990). The Fifth Discipline. The Art \& Practice of the Learning Organization. New York, NY: Doubleday.

SFS (19077). Arbetsmiliölag. Svensk författningssamling 1977: 1160.

Simonson, B. (1989). Arbetarmakt och näringspolitik: LO och inflytandefrågorna 1961-1982. Stockholm: Allmänna förlaget.

Sørensen, O. H., Hasle, P., Rønne Hesselholt, R., and Herbøl, K. (2012). Nordiske forskningsperspektiver på arbejdsmiljø-Mening, indflydelse og samarbejde. TemaNord 2012: 525. København: Nordisk Ministerråd.

Spector, P. (1986). Perceived control by employees: A meta-analysis of studies concerning autonomy and participation at work. Human Relations, 11: 1005-1016.

Sund, B. (1993). The Safety Movement. Stockholm: Arbetarskyddsnämnden.

Svensson, L. (2004). Lifelong learning: a clash between a production and a learning logic. In Garsten and Jacobsson, K. (eds) Learning to Be Employable: New Agendas on Work, Responsibility, and Learning in a Globalizing World. Houndmills, Palgrave Macmillan, pp. 83-106.

Taylor, F. W. (1911/1972). Scientific Management. Comprising Shop Management, The Principles of Scientific Management and Testimony before the Special House Committee. Westport, CT: Greenwood Press, Publishers.

Tengblad, S. (2006). Is there a 'new managerial work'? A comparison with Henry Mintzberg's classic study 30 years later. Journal of Management Studies, 43(7): 1437-1461.

Theorell, T. (ed.) (2003) Psykosocial miljö och stress. Lund: Studentlitteratur.

Theorell, T. (2006). I spåren av 90-talet. Karolinska Institutet, University Press.

Thompson, P. and Warhurst, C. (eds.) (1998). Workplaces of the Future. London: Macmillan Press.

Thorsrud, E. and Emery, F. (1969). Mot en ny bedriftsorganisasjon. Oslo: Tanum Forlag.

Thylefors, I. (2008). Psychosocial work environment. In Boghard, Mats, et al. (eds) Work and Technology on Human Terms. Stockholm: Prevent.

Trist, E. L. and Bamforth, K. W. (1951). Some social and psychological consequences of the longwall method of coal-getting, Human Relations, 4(1): 3-38.

Warr, P. (1994). A conceptual framework for the study of work and mental health. Work and Stress, 8(2): 84-97.

Westgaard, R. H. and Winkel, J. (2011). Occupational musculoskeletal and mental health: Significance of rationalization and opportunities to create sustainable production systems-A systematic review. Applied Ergonomics, 42: 261-296.

Womack, J. P., Jones, D. T. and Roos, D. (1990). The Machine That Changed the World. New York, NY: McMillan, Rawson Associates. 